\title{
Meiofaunal responses to sedimentation from an Alaskan spring bloom. I. Major taxa
}

\author{
John W. Fleeger ${ }^{1}$, Thomas C. Shirley ${ }^{2}$, David A. Ziemann ${ }^{3}$ \\ ${ }^{1}$ Department of Zoology and Physiology, Louisiana State University, Baton Rouge, Louisiana 70803, USA \\ ${ }^{2}$ Juneau Center for Fisheries and Ocean Sciences, University of Alaska Fairbanks, Juneau, Alaska 99801, USA \\ ${ }^{3}$ Oceanic Institute, Makapuu Point, PO Box 25280, Honolulu, Hawaii 96825, USA
}

\begin{abstract}
Metazoan meiofaunal community dynamics and spring phytoplankton bloom sedimentation rates were measured concurrently in Auke Bay, Alaska, from 1985 to 1988 . We test the null hypothesis that recruitment and density maxima are unrelated to sedimentation events. Springtime chlorophyll a sedimentation was predictable and episodic, occurring annually at peak rates during midMay at $35 \mathrm{~m}$; carbon sedimentation was continuous through the spring. Cumulative sedimentation varied from year to year, ranging from lowest to highest by a factor of 2 . At a $30 \mathrm{~m}$ station, seasonal variation in major taxon density was not identifiable, however interannual variations in meiofaunal densities did occur No consistent relationship between meiofaunal abundances and spring chl a or carbon sedimentation was found, i.e. years with the highest or lowest nematode and harpacticoid abundances did not correspond to years with the highest or lowest values for sedimentation. Other factors must regulate the interannual variation in meiofauna, at least over the range of values for sedimentation in Auke Bay.
\end{abstract}

\section{INTRODUCTION}

Although there have been many recent ecological studies of the meiobenthos (Coull \& Bell 1979), most research has been estuarine, or set in intertidal or in very shallow subtidal habitats. When deeper water locales (e.g. continental shelves or even coastal embayments) are studied, collection designs (and research budgets) rarely permit repeated sampling over more than one season or year (Coull et al. 1982). Nevertheless, some trends for subtidal meiofauna are apparent Measurements of meiofaunal densities range from $10^{5}$ $\mathrm{m}^{-2}$ to an order of magnitude more if proper techniques are followed (Coull \& Bell 1979, Rudnick et al. 1985), and there is interannual variation in abundance (Coull 1985). Seasonality is sometimes apparent with peaks in late spring to early summer in temperate areas (Hicks \& Coull 1983, Coull 1985, Rudnick et al. 1985). Unfortunately, the regulation of abundance within a given site is poorly understood although predictable trends occur with latitude and water depth (Coull et al. 1982, Pfannkuche \& Thiel 1987).

One factor frequently mentioned as a possible regulator of subtidal meiofauna is phytoplankton sedimentation. Phytoplankton during and after bloom condi- tions may settle quickly to the bottom (Billett et al. 1983, Townsend \& Cammen 1988), and settled cells may be in good physiological and nutritional condition (Lenz 1977). Sedimented phytoplankton might be directly ingested (Decho 1986, Gooday 1988), or become part of the microbial loop, ultimately increasing meiofaunal food supplies (Rudnick 1989). Thus variation in phytoplankton settlement might affect meiofaunal survivorship and reproductive success.

Marine ecologists have long sought relationships between water column productivity and the benthos. The influence of water column production on benthic metabolism (Hargrave 1973) and microbial activity (Graf et al. 1983, Meyer-Reil 1983) is best understood. Relationships between faunal characteristics (density, biomass and diversity) and phytoplankton sedimentation have proven elusive (see Mann 1976 and Grebmeier et al. 1988 for exceptions). One reason is the rarity of multi-year baseline studies which adequately monitor sedimentation and faunal densities. This situation is particularly acute for meiofauna, and alternative approaches have been developed. In mesocosms, nutrients have been added to the water column to stimulate phytoplankton growth, however, an intimate association between water column sedimentation and 
meiofaunal abundance was not found (Widbom \& Elmgren 1988). More baseline studies are needed, not only to discover if fundamental trophic links exist in nature, but to determine how best to conduct future manipulative studies.

The work described here was conducted as part of the APPRISE (Association of Primary Production and Recruitment in a Subarctic Ecosystem) project, a 5 yr study with the goal of increased understanding of the linkages between physical and biological characteristics associated with the spring bloom in subarctic waters. The objective of this study was to examine spring phytoplankton bloom sedimentation and its possible effects on meiofauna over 4 annual cycles. By quantifying interannual variation in the timing and intensity of sedimentation, coupled with estimation of meiofaunal abundance and recruitment, we test the null hypothesis that meiofauna do not respond to sedimentation events

\section{METHODS}

Sampling was conducted in Auke Bay, Alaska $\left(58^{\circ} 22^{\prime} \mathrm{N}, 134^{\circ} 40^{\prime} \mathrm{W}\right)$, ca $20 \mathrm{~km}$ north of Juneau. Auke Bay is a partially enclosed embayment with an area of ca $10 \mathrm{~km}^{2}$ in a system of fjords connected with the Pacific Ocean. About $50 \%$ of the bay is between 40 and $60 \mathrm{~m}$ depth with a muddy substrate. The bay has semidiurnal tides with amplitudes between 3 and $7 \mathrm{~m}$. Bottom water temperatures at $25 \mathrm{~m}$ vary between 3 and $7^{\circ} \mathrm{C}$ annually with salinities varying from 29 to $32 \mathrm{ppt}$ annually (Coyle \& Shirley 1986). Runoff from the Mendenhall River brings glacial flour to the bay seasonally.

Sedimentation collections. Total water column particulate flux (chlorophyll $a$ and carbon) to the bottom was determined with sediment traps (Knauer \& Martin 1981, Betzer et al. 1984). Sediment traps consisted of a $15 \mathrm{~cm}$ diameter, $45 \mathrm{~cm}$ long PVC tube capped at one end and attached to a taut tether with a bottom anchor and a subsurface float. The sediment trap was retrieved, emptied and replaced twice a week for the field season. Material collected in the trap was emptied into a polyethylene bucket upon retrieval for further analysis on shore. The trap was then refilled with filtered seawater, and an $80 \mathrm{~g}$ salt tablet was added to form a density gradient which reduced possible losses due to resuspension and mixing. In actual practice, the particulate material collected in the trap was always found as a layer in the bottom of the trap with an overlying layer of clear water. Traps were placed at 3 Auke Bay locations from 1985 to 1989 at various depths (Table 1). We will focus on traps at $35 \mathrm{~m}$ at Auke Bay Monitor (ABM) because this station was occupied each year and because of its similarity with the depth of the primary meiofaunal collection site, East (E) Station. Two other stations, $E$ and North (N), were sampled in 1987 to provide a broad view of sedimentation spatial variability in Auke Bay.

Chlorophyll and pheopigment concentrations were determined via the fluorometric method for acetoneextracted samples (Holm-Hansen et al. 1965, Strickland \& Parsons 1972). Samples for pigment analysis were collected on $0.4 \mu \mathrm{m}$ Nuclepore polycarbonate filters, extracted in the dark overnight at $5^{\circ} \mathrm{C}$ and measured with a Turner Designs fluorometer calibrated against pure chlorophyll extract. Particulate carbon samples were collected on precombusted Whatman $\mathrm{GF} / \mathrm{F}$ glass fiber filters and analyzed in a HewettPackard Model $185 \mathrm{C}-\mathrm{H}-\mathrm{N}$ analyzer according to Gordon (1969) and Sharp (1974).

Meiofaunal collections. Three different locations were sampled regularly for at least one field season to provide biological and physical databases (Table 1). The most extensive meiofaunal collections were from East Station, $27 \mathrm{~m}$ water depth, with collections from 1985 to 1988 . In 1985 samples were collected at about $10 \mathrm{~d}$ intervals from April 3 to June 10; in 1986 samples were obtained at about $7 \mathrm{~d}$ intervals from May 8 to August 7, with an additional collection on October 30 . In 1987 additional stations, Auke Bay Monitor (at $50 \mathrm{~m}$ ) and North (at $42 \mathrm{~m}$ ), were sampled to provide better

Table 1. Sampling regime for sedimentation and meiofaunal collections in Auke Bay. Numbers in parenthesis represent depth of sediment traps or water column depth. ABM: Auke Bay Monitor

\begin{tabular}{|lcccc|} 
& 1985 & 1986 & 1987 & 1988 \\
\hline Sediment trap field season & & & & \\
ABM $(35 \mathrm{~m})$ & $25 \mathrm{Mar}-27$ May & $14 \mathrm{Mar}-23 \mathrm{Jun}$ & $16 \mathrm{Mar}-25 \mathrm{Jun}$ & 14 Mar-2 June \\
North $(35 \mathrm{~m})$ & - & - & $2 \mathrm{Apr}-25 \mathrm{Jun}$ & - \\
East $(20 \mathrm{~m})$ & - & - & $2 \mathrm{Apr}-25 \mathrm{Jun}$ & - \\
Meiofauna field season & - & - & 1 Apr-3 Dec & - \\
ABM $(50 \mathrm{~m})$ & - & - & 1 Apr-19 Aug & - \\
North $(42 \mathrm{~m})$ & 3 Apr-10 June & 8 May-7 Aug, 30 Oct & 1 Apr-3 Dec & 16 Mar-22 Jun \\
East $(27 \mathrm{~m})$ & &
\end{tabular}


resolution of spatial variability throughout the bay. In addition, 1987 was chosen to investigate a broader time window; samples were collected at about $7 \mathrm{~d}$ intervals from April 1 to August 19, and then monthly from September through December at E and ABM. In 1988, samples were obtained weekly from March 16 through June 22. These stations were chosen partially because they were similar in sediment texture, consisting of soft muds with little sand.

After May 1985, all meiofaunal samples were collected by a tom-tom corer. The 2 earliest collections (in April 1985) were taken by an van Veen grab, and subsampled with small, hand-held corers. Tom-tom and van Veen grabs were subsequently taken simultaneously and analysis indicated that the van Veen grab under-sampled meiofauna by a factor of 1.5 to 3 (Chandler et al. 1988). Data from the van Veen grabs are reported here to provide as long a record of density estimates as possible. The tom-tom, on the other hand, is an efficient, flow-through style, multiple corer, designed to collect meiofauna in relatively calm waters (Chandler et al. 1988). The corer was always deployed slowly to reduce bow-wave effects. In 1985 and 1986, at least 2 casts of the tom-tom were taken to obtain a maximum of 8 replicates. In 1987 and 1988, one cast was made to obtain as many as 4 replicates. In 1985, each core was subsampled with a syringe style corer; thereafter, the entire tom-tom core was retained and sorted whole. Routinely, the upper $2.5 \mathrm{~cm}$ of sediment was retained by the use of a core extruder foccasionally whole cores slipped out of the tom-tom before extrusion, and were retained in a jar in their entirety), and returned to the laboratory. Most samples were extracted with sucrose flotation (Fleeger 1979). In 1986, a few samples were extracted with LUDOX (Jonge \& Bouwman 1977) after a large settlement of diatoms reduced sucrose extraction efficiency. Estimates suggest that sucrose extraction was normally very efficient, $95 \%$ for nematodes and $98 \%$ for copepods. All material retained on a $63 \mu \mathrm{m}$ sieve was sorted under a stereomicroscope. In 1985 and 1986, samples were sorted in ruled trays and all fauna enumerated; in 1987 and 1988 the methods of Sherman et al. (1984) were employed to subsample nematodes while completely sorting rarer taxa. Major taxa, except Foraminifera, were enumerated. Copepods (adults and copepodites) were removed and retained for later identification to species (Fleeger \& Shirley unpubl).

\section{RESULTS}

\section{Physical variables}

A spring phytoplankton bloom and its accompanying chlorophyll (chl) a sedimentation appears to be a pre- dictable, annual event in Auke Bay (Ziemann et al. 1988). During the years under investigation, sedimentation occurred throughout the spring, but was extremely intense for a brief period (Fig. 1a). For example, about $40 \%$ of the total chl a sedimentation for the spring reached the $35 \mathrm{~m}$ sediment trap at $A B M$ during only a $10 \mathrm{~d}$ interval in 1985 and 1986. Furthermore, the timing of this episode was remarkably constant across years at a given depth, always occurring in mid-May at $35 \mathrm{~m}$. Although the carbon flux (Fig. 1b) was also seasonal, the signal was not as strong. Increases in carbon flux were consistent throughout May, but in 1985 and 1986 the increase was steep while in 1987 and 1988 it was more gradual.

Although timing was similar across years, the total, or cumulative, sedimentation through June varied interannually in Auke Bay. Chl a sedimentation at ABM was high in the 1985, 1986 and 1987 spring
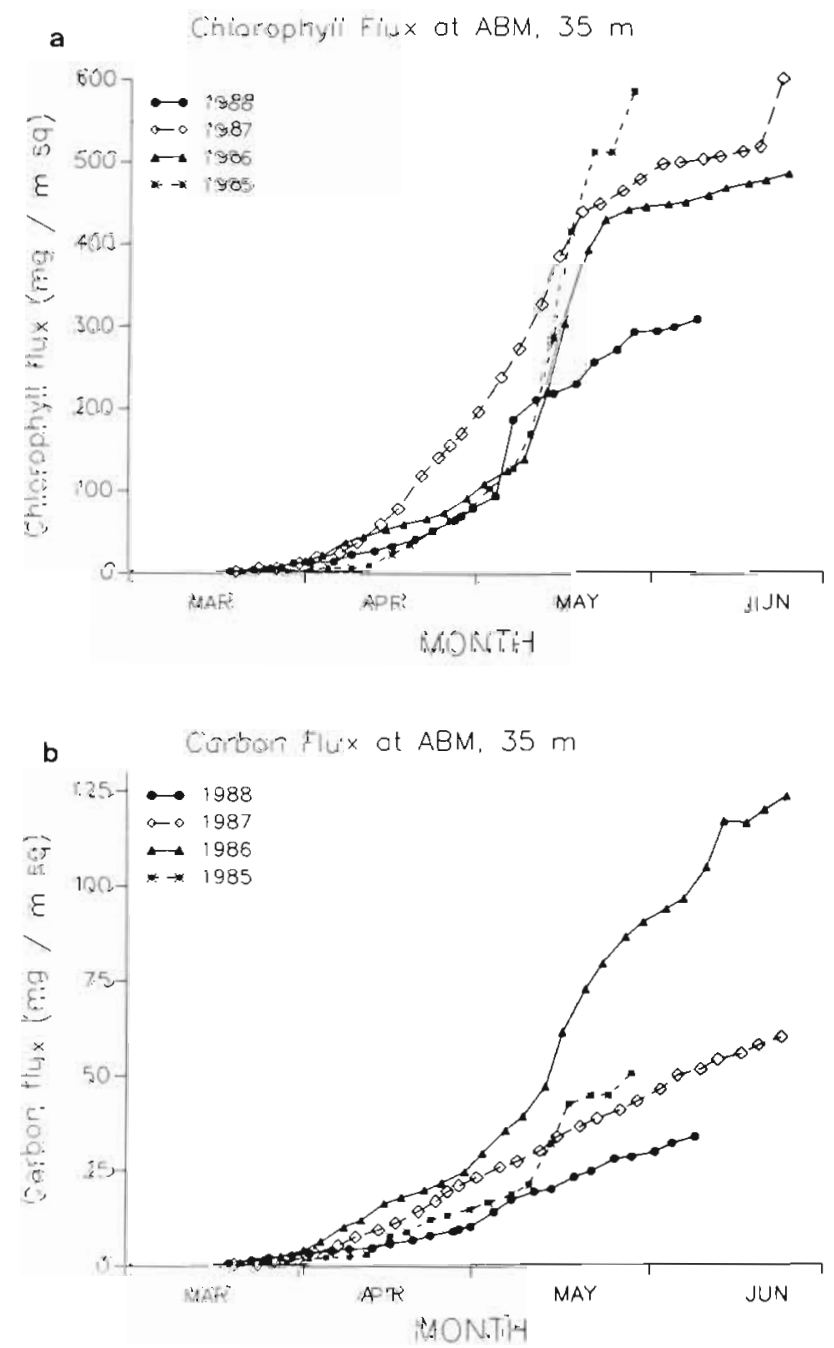

Fig. 1. Sedimentation $\left(\mathrm{mg} \mathrm{m}^{-2}\right)$ as measured in sediment traps suspended at $35 \mathrm{~m}$ at ABM Station in Auke Bay, Alaska, 1985 to 1988. (a) Chlorophyll a, (b) carbon. Values are cumulatively summed during the field season 
seasons, with fluxes about 500 to $600 \mathrm{mg} \mathrm{m}^{-2}$, while 1988 was low with a flux of about $300 \mathrm{mg} \mathrm{m}^{-2}$ (Fig. 1a). Total carbon flux was also similar in 3 of the $4 \mathrm{yr}$ (Fig. 1b). Carbon flux was highest in 1986 (ca $125 \mathrm{mg}$ $\mathrm{m}^{-2}$ ), and about twice that of other years. In 1987, traps were also placed at ABM (20 m), North $(35 \mathrm{~m})$ and East $(20 \mathrm{~m})$ Stations to provide a broader view of spatial variability in Auke Bay (Ziemann et al. 1988). Although E $20 \mathrm{~m}$ sedimentation (chl a and carbon) was higher and slightly earlier than the ABM $35 \mathrm{~m}$ station, ABM and $E$ values at $20 \mathrm{~m}$ were very similar (Fig. 2). Values at $\mathrm{N}$ at $20 \mathrm{~m}$ were consistently lower (by half) than $\mathrm{ABM}$ or $\mathrm{E}$ at similar depths (Figs. 1 and 2).

Temperatures were similar in 1985 and 1986 with near-bottom water staying at or close to $3.5^{\circ} \mathrm{C}$ for March and April, then warming as the season progressed, reaching 4.5 to $5^{\circ} \mathrm{C}$ in June/July (Fig. 3a). In 1987

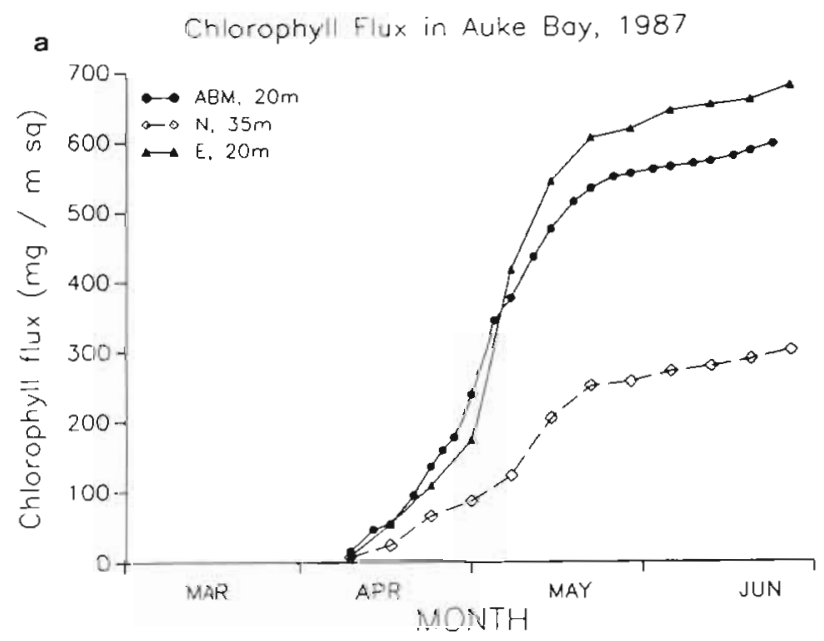

b Carbon Flux in Auke Boy, 1987

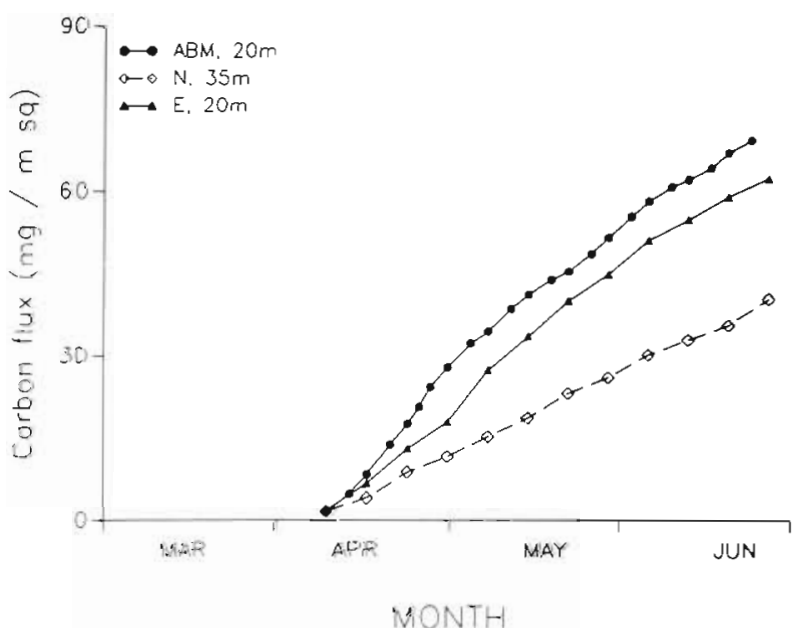

Fig. 2. Sedimentation ( $\mathrm{mg} \mathrm{m}^{-2}$ ) as measured in sediment traps suspended at various depths at stations in Auke Bay in 1987. (a) Chlorophyll a, (b) carbon. Values are cumulatively summed during the field season a Woter $(30 \mathrm{~m})$ temperoture in Auke Bay

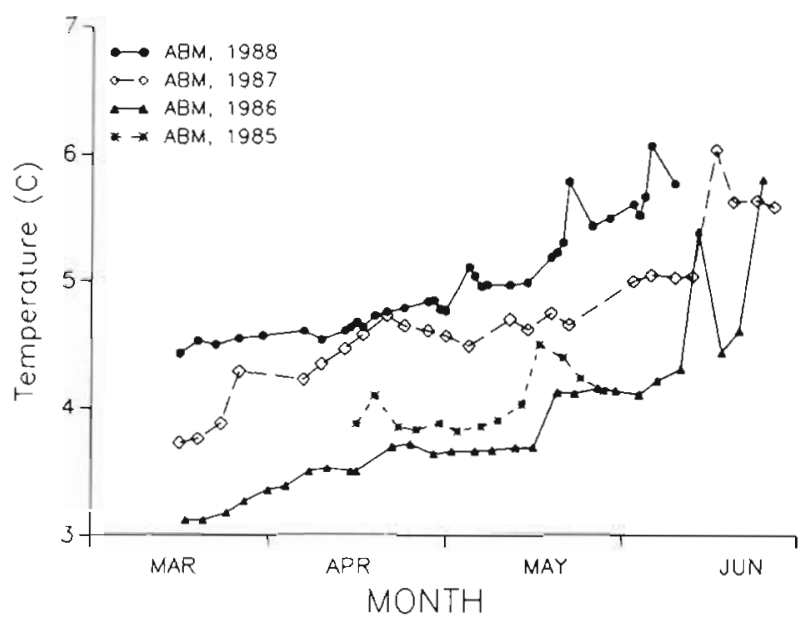

b Water temperature in Auke Bay, 1987

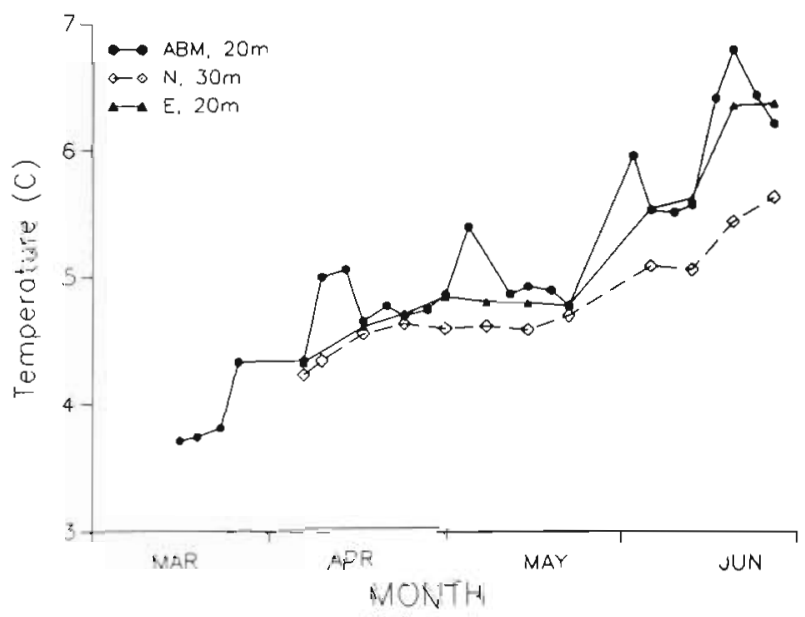

Fig. 3. Water temperatures $\left({ }^{\circ} \mathrm{C}\right.$ ) in Auke Bay. (a) ABM Station at $30 \mathrm{~m}$ depth, 1985 to 1988 , (b) 3 stations in 1987

and 1988, water temperatures began the field season warmer and remained about $1{ }^{\circ} \mathrm{C}$ higher through early summer. Temperatures at $20 \mathrm{~m}$ at ABM, N and E were similar to each other in 1987, as only ABM exceeded others, perhaps with a tidal rhythmicity (Ziemann et al. 1988). All 3 sites warmed at similar rates through the spring (Fig. 3b).

\section{Meiofaunal dynamics}

Nematodes were always the most abundant metazoan taxon, comprising $97 \%$ of the total meiofauna across all dates and stations. Because of this overwhelming predominance, total meiofaunal and nematode abundances follow identical trends, and total meiofauna will not be discussed further. Copepods 

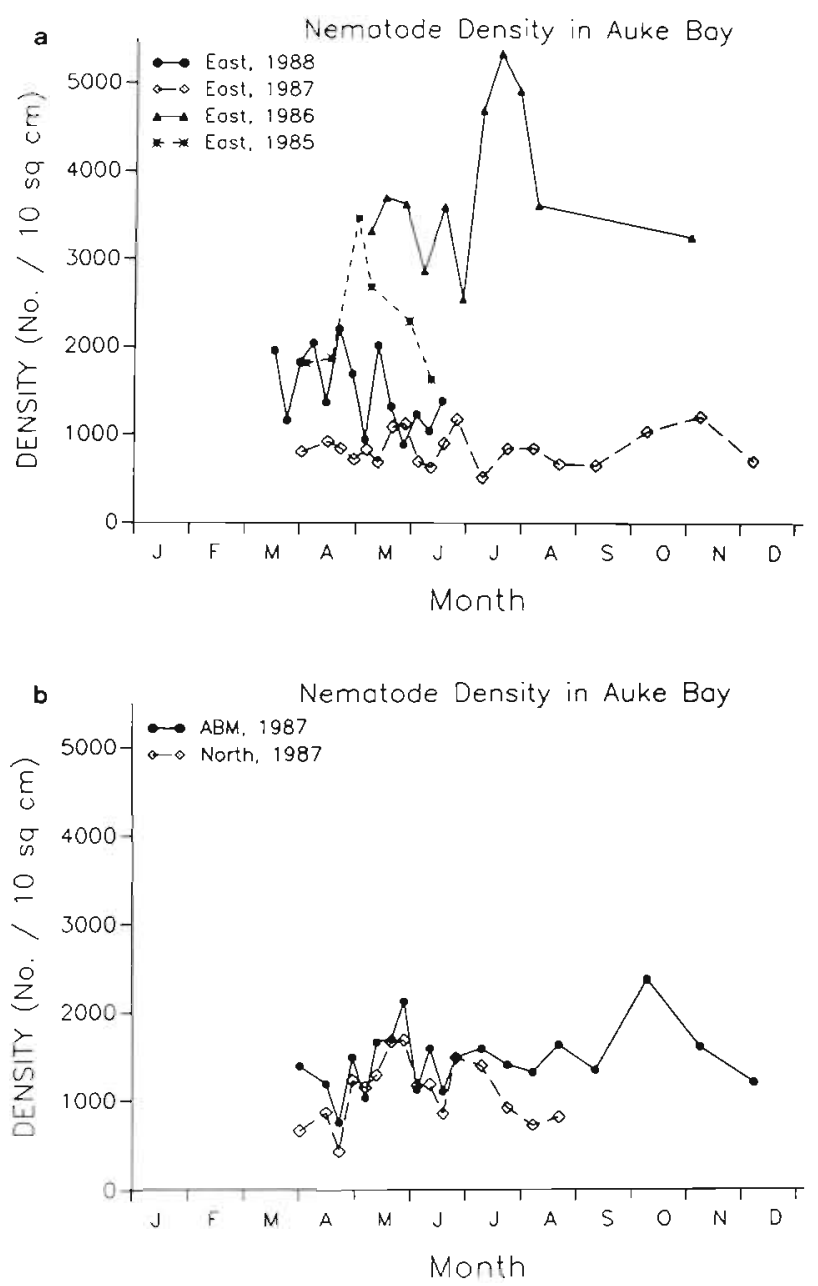

Fig. 4. Mean nematode density (ind. $10 \mathrm{~cm}^{-2}$ ) in Auke Bay. (a) East Station, 1985 to 1988, (b) 2 stations in 1987

(adults and copepodites) were the second most abundant taxon $(1.3 \%$ of the total) and copepod nauplii were consistently present $(0.6 \%$ of the total). Other groups include permanent and temporary meiofauna. Priapulids, which were seasonally very abundant as larvae (Shirley 1989), larval and juvenile polychaetes, gastrotrichs and kinorhynchs were regularly found but in low abundance.

Trends in nematode abundance were very different among years in Auke Bay (Fig. 4a). Within a given year, nematode densities tended to fairly closely fluctuate around the mean for that year (e.g. the mean 1986 density was 3759 and the range was from 2546 to 5339 ind. $10 \mathrm{~cm}^{-2}$ ). Different years were clearly distinct from each other in mean abundance. For example, all 1986 values were higher than any reported from 1987 or 1988. Numerically, 1986 was the year with highest densities, 1985 was second (mean of 2107), 1988 was third with a mean of 1526 and 1987 the lowest with a mean of 846 ind. $10 \mathrm{~cm}^{-2}$. No evidence for seasonality was present for nematode abundance. Two large increases in density took place (one in June 1986, the other in April 1985), but did not occur in the same season. In fact the April 1985 increase could have been due to the change in methodology as it coincides with the initiation of the use of the tom-tom corer rather than the van veen grab.

Variability may exist at many spatial scales. Within a single collection (all samples taken at a station on one date) nematode variation was surprisingly low. In 1986 (the least variable year), the standard error averaged only $9.2 \%$ of the mean, and in 1985 (the most variable year), it was $17.8 \%$ of the mean. In 1987 and 1988 this value rarely exceeded $15 \%$ of the mean. A nested ANOVA reveals that dates, but not separate casts of the sampler, were a significant source of variation for nematodes in 1985. In 1986 this pattern was reversed. At a larger spatial scale (Fig. 4b), 1987 collections were low in abundance at all Auke Bay sites (Shirley et al. 1988).

Harpacticoid densities were also quite different between years (Fig. 5a). In 1985 and 1986, harpacticoids increased in numbers suddenly (seasonally?), reaching densities higher than $90 \mathrm{ird} .10 \mathrm{~cm}^{-2}$. The increase in 1986 was, however, abou: 6 wk later than the 1985 increase. In 1987, densities remained low throughout the year (never exceeding 25 ind. $10 \mathrm{~cm}^{-2}$ ), while in 1988 they fluctuated greatly from collection to collection but averaged around 50 ind. $10 \mathrm{~cm}^{-2}$. The low 1987 values (averaging about 15 ind. $10 \mathrm{~cm}^{-2}$ compared with 36 to 50 ind. $10 \mathrm{~cm}^{-2}$ in other years) occurred throughout Auke Bay (Shirley et al. 1988) indicating little spatial variability within a year (Fig. 5b). Within collection variability was relatively high for harpacticoids, as standard errors averaged about $25 \%$ of the mean. In 1985 and 1986, nested ANOVA shows that dates added significant variation, while variation added by replicate casts of the sampler was not significan:

\section{DISCUSSION}

Meiofaunal collections were primarily from East Station at $27 \mathrm{~m}$, while most sedimentation data was obtained from Auke Bay Monitor Station at $35 \mathrm{~m}$ (the 2 stations are about $1200 \mathrm{~m}$ apart). Benthic and sedimentation collections from both sites (as well as North Station) were obtained in 1987 to examine spatial variability in the bay. All Auke Bay sites proved to be very similar physically (e.g. sediment type, sedimentation inputs) and faunistically. Sedimentation was slightly higher and earlier at the $20 \mathrm{~m}$ trap at E compared to the $35 \mathrm{~m}$ trap at ABM, but such differences can be explained by the difference in depth of the traps. Temperature increases were similar at the 2 sites, and meiofaunal abundances were uniformly low through- 

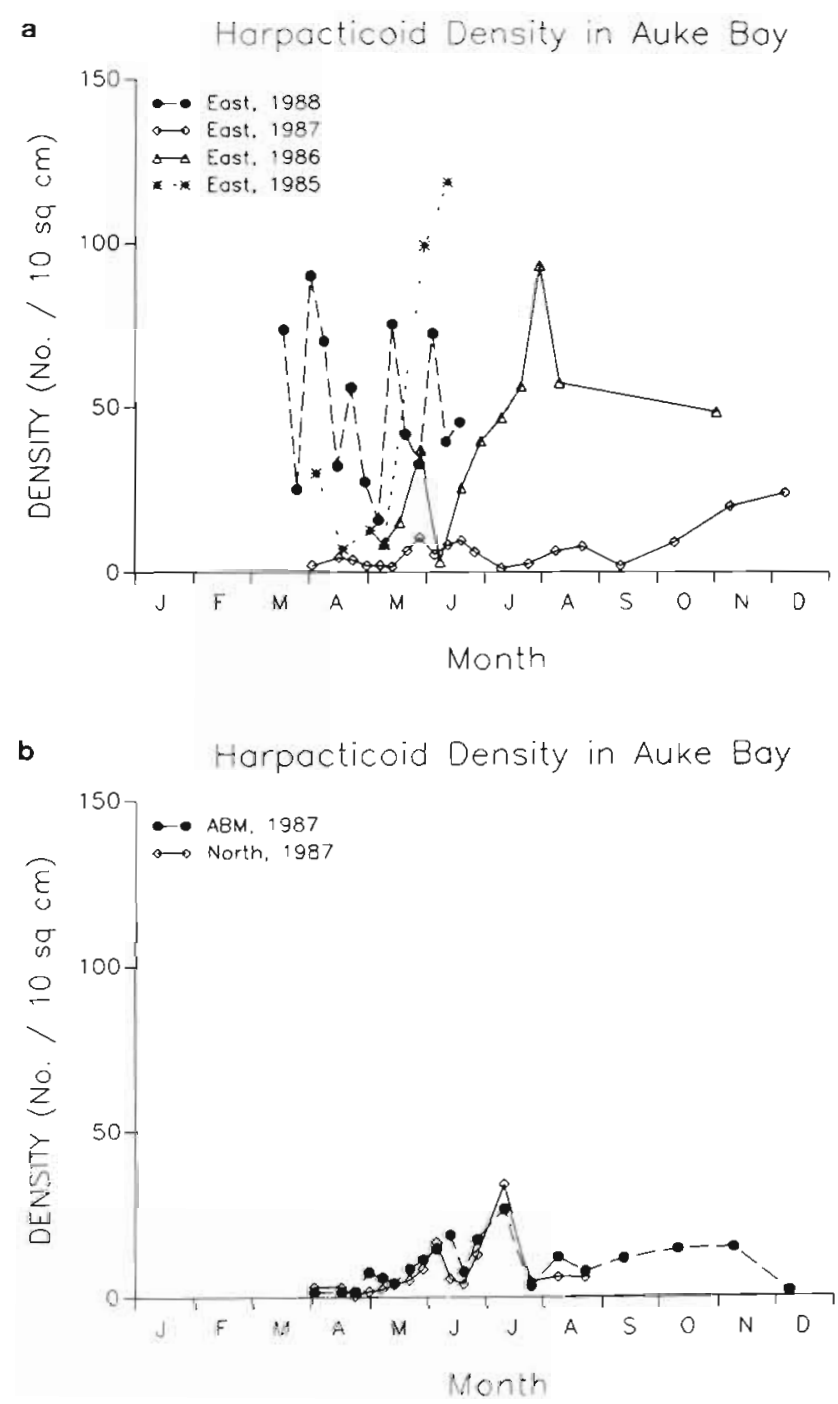

Fig. 5. Mean harpacticoid copepod density (ind. $10 \mathrm{~cm}^{-2}$ ) in Auke Bay. (a) East Station, 1985 to 1988, (b) 2 stations in 1987

out 1987. Consequently, we feel justified in relating $A B M$ sedimentation trends with $E$ meiofaunal density patterns.

We address 2 separate questions here: does interannual variation in sedimentation control peak spring or summer meiofaunal abundance, and, is meiofaunal recruitment coupled with sedimentation? The phytoplankton bloom and its subsequent sedimentation is clearly episodic and highly seasonal in Auke Bay (Fig. 1). Peak chl a sedimentation occurred around mid-May. Between years, total chl a sedimentation was high and similar in 1985, 1986 and 1987 but lower by about half in 1988. Carbon sedimentation was highest in 1986 and roughly equal in other years.

No indication is present for a tight relationship between spring or summer meiofaunal density increases or maxima and cumulative springtime sedimentation. Nematodes were consistently high in
1986, and low in 1987, but neither instance corresponded to highs or lows in chl a sedimentation amounts (although 1986 was the highest year for carbon sedimentation). Harpacticoid densities also poorly correlated, with highs in 1985 and 1986, very low values in 1987 and moderate ones in 1988. Recruitment is also problematic as no meiofaunal major taxon showed dramatic increases in numbers at times related to the input of sedimented material (species of harpacticoid copepods and their recruitment patterns will be discussed in a separate paper, Fleeger \& Shirley unpubl.)

Nematodes, as a group, display a variety of feeding modes ranging from deposit-feeding to selective diatom herbivory (Jensen 1987). We did not identify nematodes to species or feeding group and certainly component species or trophic groups may have responded to the sedimentation event. Nematodes, however, have been shown to respond to increased bacterial concentrations with increased densities (Montagna et al. 1987), and are relatively deep-dwelling. Therefore many nematodes may not be able to directly utilize planktonic diatoms (the predominant sedimenting algae; Laws et al. 1988) as food, and they may rely on the 'microbial loop' (Lopez \& Levinton 1987) to stimulate bacterial production from sedimentation. If this is true, one might not expect rapid nematode density changes, and time-lags (Montagna et al. 1983) between density increases and sedimentation would occur. Time lags of a short duration have been reported between sedimentation and foraminiferan abundances (Faubel et al. 1983). Longer lags may be the case in Auke Bay as nematodes were roughly consistent in abundance within a year, but exhibited strikingly different patterns between years. In fact, the highest nematode densities (1986) followed the year of highest chl a sedimentation intensity (1985) which suggests a time-lagged interaction. Alternatively, the highest carbon sedimentation was in 1986 when nematodes numbers were at their highest levels (1987 numbers were uniformly low). Carbon sedimentation in other years was roughly equal but nematode numbers varied widely among them. Better unerstanding of the food resources of the nematode community is needed before it is possible to further interpret our results, although Rudnick (1989) found that larger, deeperdwelling nematodes are probably not directly dependent on surface-deposited phytodetritus.

In the laboratory, harpacticoids are known to assimilate sedimented planktonic diatoms (Decho 1986), and surface-dwelling harpacticoids have been shown to quickly incorporate phytodetritus (Rudnick 1989). Preliminary evidence suggests that several Auke Bay harpacticoids directly utilize sedimented planktonic diatoms as food (Shirley et al. 1987). The early bloom in 
all years was dominated by species of the genera Thalassiosira and Skeletonema (Laws et al. 1988) which have been used to culture harpacticoids (Chandler 1986). Harpacticoids are surficial in depth distribution (Palmer 1984), and their field densities have been related to standing stocks of diatoms (Montagna et al. 1983, Decho \& Fleeger 1988). Given these facts, it was surprising that harpacticoid density increases and maxima were unrelated to sedimentation intensity. Temperature also does not seem to have had a strong influence on density (higher temperatures might increase growth rates). Temperatures were low in high abundance years of 1985 and 1986, but high in the low abundance years. Other factors, e.g. reproduction and predation, must have played a role in abundance regulation of individual species.

We know little about the possibility of a fall phytoplankton bloom in Auke Bay because it is little studied (Coyle \& Shirley 1986), but fall blooms can be significant in other systems (Graf 1987). A heavy fall bloom could increase winter survivorship or provide higher reserves of food in the spring, thus stimulating increased densities at the beginning of the next growth season. Variations in initial density due to fall sedimentation variations might effect growth rates early in the year, and could explain year to year variations in summer densities.

Previous studies comparing macro- and meiofaunal densities with phytoplankton sedimentation intensity are contradictory. Some field studies with macrofauna (Graf et al. 1983, Graf et al. 1984, Valderhaug \& Gray 1984) have found highly stable population densities even though phytoplankton input varied seasonally, while others (Rudnick et al. 1985, Grebmeier et al. 1988) suggest a seasonal or spatial response to high sedimentation rates.

Meiofaunal studies are similarly unclear. Faubel et al. (1983) and Graf et al. (1983) suggest a time-lagged (weeks to months) increase in meiofauna densities after sedimentation input, however these studies were for only a single year and in one case (Graf et al. 1983) sampling intensity and technique were suspect. The present study found no unequivocal influence of sedimentation on meiofaunal abundances. Only Rudnick et al. (1985) in Narragansett Bay found consistent seasonal increases in meiofauna coincident with phytoplankton sedimentation. This study was however conducted at a shallow depth $(7 \mathrm{~m})$ and at seasonally warm temperatures $\left(17^{\circ} \mathrm{C}\right)$ which suggest that benthic diatom production could have been partially responsible for the seasonal increases in meiofaunal densities. In a mesocosm experiment (Widbom \& Elmgren 1988), also in Narragansett Bay, nutrients were added to the water column in tanks to stimulate phytoplankton production and sedimentation. Unfortunately, meioben- thic responses were highly variable in enriched mesocosms, and the authors believe that, under enrichment, factors other than food availability become important in limiting the meiobenthic community. In another mesocosm study, Gee \& Warwick (1985) found increases in abundance of harpacticoids (but not nematodes) and major changes in harpacticoid community structure when organic matter was added to sediments from $35 \mathrm{~m}$ depth. The organic matter was added in amounts similar to annual phytoplankton sedimentation, and suggests that food increases were critical to the increased densities. Given such contrasting results, it seems impossible to generalize a simple, monotonic relationship between sedimentation and faunal abundance.

Pfannkuche \& Thiel (1987), working in a range of depths into the deep-sea, found that meiofaunal standing crop is related to sediment 'chlorplastic' pigments probably derived from phytoplankton sedimentation. This relationship spanned an order of magnitude in meiofaunal abundances (much more than other studies have encountered) and depths from 240 to $3920 \mathrm{~m}$. At present we cannot generalize an interannual relationship between meiofaunal abundance and sedimentation within a given site. Perhaps it is most likely to occur when orders of magnitude differences in inputs and densities are compared, e.g. the continental shelf to deep-sea gradient.

Phytoplankton sedimentation in Auke Bay is distinctly seasonal, while meiofaunal density and biomass lack strong seasonality. Interannual variability in sedimentation and faunal densities exist. However highs and lows correspond poorly with each other. Many explanations for the absence of correlations are possible. For example, variation in sedimentation from year to year may not be great enough to cause interannual variation in abundance in Auke Bay. From 1985 to 1988 , sedimentation differed at most by a factor of 2 . Aiternatively, meiofauna may reproduce at higher rates during or shortly after peak sedimentation conditions but be prevented by predation from increasing in density. Evidence suggests that predation intensity on shallow subtidal meiofauna is high in Auke Bay. Sturdevant (1987) found that some members of a suite of postmetamorphic flatfish feed heavily on harpacticoid copepods, and salmon are known to be voracious harpacticoid feeders (Cordell 1986). Perhaps the greatest problem is that food webs involving the meiobenthos are poorly known. Rudnick (1989) suggests that the benthos may exist in 2 units, a surface-oriented fauna which directly relies on phytodetritus as food and a subsurface fauna which utilizes refractory organic carbon. Until these trophic relationships are understood, interpretation of findings such as ours must be considered tentative. 
Acknowledgements. We thank $T$ Chandler, A. Decho, J McCall, S. McGregor, L. McNutt, M. Sturdevant, H. Nguyen and $\mathrm{K}$. Welch for sample sorting. J. McCall commented on an earlier draft of the manuscript. D. Erickson and M. Broderson, skippers of the RV 'Maybeso', are thanked for their assistance. The Auke Bay Labs, NMFS, kindly permitted use of their dock facilities. Funding was provided to the Juneau Center for Fisheries, University of Alaska, Fairbanks, as part of APPRISE, by the National Oceanic and Atmospheric Administration contract no. NA-85-ABH-022.

\section{LITERATURE CITED}

Betzer, P. R., Showers, W. J., Laws, E. A., Winn, C. D. DiTullio, G. R., Kroopnick, P. M. (1984). Primary productivity and particle fluxes on a transect of the equator at $153^{\circ} \mathrm{W}$ in the Pacific Ocean. Deep Sea Res. 31. 1-11

Billett, D. S. M., Lampitt, R. S., Rice, A. L., Mantoura, R. C. F. (1983). Seasonal sedimentation of phytoplankton to the deep-sea benthos. Nature, Lond. 302: 520-522

Chandler, G. T. (1986). High density culture of meiobenthic harpacticoid copepods within a muddy sediment substrate. Can. J. Fish. Aquat. Sci. 43: 53-59

Chandler, G. T., Shirley, T. C., Fleeger, J. W. (1988). The tomtom corer; a new design of the Kajak corer for use in meiofauna sampling. Hydrobiologia 169: 129-134

Cordell, J. R. (1986). Structure and dynamics of an epibenthic harpacticoid assemblage and the role of predation by juvenile salmon. M.S. thesis, Univ. of Washington, Seattle

Coull, B. C. (1985). Long-term variability of estuarine meiobenthos: an 11 year study. Mar. Ecol. Prog. Ser 24: $205-218$

Coull, B. C., Bell, S. S. (1979). Perspectives of marine meiofaunal ecology. In: Livingston, R. J. (ed.) Ecological processes in coastal and marine systems. Plenum Publishing Corp., New York, p. 189-216

Coull, B. C., Zo, Z., Tietjen, J. H., Williams, B. S. (1982). Meiofauna of the southeastern United States continental shelf. Bull. mar. Sci. 32: 139-150

Coyle, K. O., Shirley, T. C. (1986). A summary of the fisheries and oceanographic research in Auke Bay, Alaska and vicinity. In: APPRISE Annual Report. Summary of the 1985 APPRISE Research Program. University Alaska Juneau, Juneau, p. 7-142

Decho, A. W. (1986). Water-cover influence on diatom ingestion rates by meiobenthic copepods. Mar. Ecol. Prog. Ser. 33: $139-146$

Decho, A. W., Fleeger, J. W. (1988). Microscale dispersion of meiobenthic copepods in response to food-rescource patchiness. J. exp. mar. Biol. Ecol. 118: 229-244

Faubel, A., Hartwig, E., Thiel, H. (1983). On the ecology of the benthos of sublittoral sediments, Fladen Ground, North Sea I. Meiofauna standing crop and estimation of production. 'Meteor' Forsch-Ergebn. 36: 35-48

Fleeger, J. W (1979). Population dynamics of three estuarine meiobenthic harpacticoids (Copepoda) in South Carolina. Mar. Biol. 52: 147-156

Gee, J. M., Warwick, R. M. (1985). Effects of organic enrichment on meiofaunal abundance and community structure in sublittoral soft sediments. J exp. mar. Biol. Ecol. 91: $247-262$

Gooday, A. J. (1988). A response by benthic Foraminifera to the deposition of phytodetritus in the deep sea. Nature, Lond. 332: 70-73

Gordon, D. C., Jr. (1969). Examination of methods of particulate carbon analysis. Deep Sea Res. 16: 660-665
Graf, G. (1987). Benthic energy flow during a simulated autumn bloom sedimentation. Mar. Ecol. Prog. Ser 39: $23-29$

Graf, G., Bengtsson, W. Faubel, A., Meyer-Reil, L.-A., Schulz, R., Theede, H., Thiel, H. (1984). The importance of the spring phytoplankton bloom for the benthic system of Kiel Bight. Rapp. P.-v. Réun. Cons. int. Explor Mer 183: $136-146$

Graf, G., Schulz, R., Peinert. R., Meyer-Reil, L.-A. (1983). Benthic response to sedimentation events during autumn to spring at a shallow-water station in the Western Kiel Bight. I. Analysis of process on a community level. Mar Biol. 77: 235-246

Grebmeier, J. M., McRoy, C. P., Feder, H. M. (1988). Pelagicbenthic coupling on the shelf of the Northern Bearing Chukci Seas. Mar Ecol. Prog. Ser. 48: 57-67

Hargrave, B. T. (1973). Coupling carbon flow through some pelagic and benthic communities. J. Fish. Res. Bd Can. 30: $1317-1326$

Hicks, G. R. F., Coull, B. C. (1983). The ecology of marine meiobenthic harpacticoid copepods. Oceanogr. mar. Biol. A. Rev. 21: $67-175$

Holm-Hansen, O., Lorenzen, C. J., Holmes, P. E., Strickland, J. D. H. (1965). Fluorometric determination of chlorophyll. J. Cons. perm. int. Explor Mer. 30: 3-15

Jensen, P. (1987). Feeding ecology of free-living aquatic nematodes. Mar. Ecol. Prog. Ser. 35: 187-196

Jonge, V. N., Bouwman, L. A. (1977). A simple density separation technique for quantitative isolation of meiobenthos using the colloidal silica Ludox-TM. Mar. Biol. 42: 143-148

Knauer, G. A., Martin, J. H. (1981). Primary production and carbon-nitrogen fluxes in the upper $1500 \mathrm{~m}$ of the Northeast Pacific. Limnol. Oceanogr. 26: 181-186

Laws, E. A., Bienfang, P. K., Ziemann, D. A., Conquest, L. D. (1988). Phytoplankton population dynamics and the fate of production during the spring bloom in Auke Bay, Alaska Limnol. Oceanogr. 33: 57-65

Lenz, J. (1977). Seston and its main components. In Rheinheimer, G. (ed.) Microbial ecology of a brackish water environment. Springer Verlag, Berlin, p. 39-60

Lopez, G. R., Levinton, J. S. (1987). Ecology of deposit-feeding animals in marine sediments. Q. Rev. Biol. 62: 235-260

Mann, K. H. (1976). Production on the bottom of the sea. In Cushing, D. H., Walsh, J. J. (eds.) The ecology of the seas W. B. Saunders Com., Philadelphia, p. 225-250

Meyer-Reil, L.-A. (1983). Benthic response to sedimentation events during autumn to spring at a shallow water station in the Western Kiel Bight. II. Analysis of benthic bacterial populations. Mar. Biol. 77: 247-256

Montagna, P. A., Bauer, J. T., Hardin, D., Spies, R. B. (1987) Temporal variability and the relationship between benthic meiofaunal and microbial populations of a natural coastal petroleum seep. J. mar. Res. 45: 761-789

Montagna, P. A., Coull, B. C., Herring, T L., Dudley, B. W (1983). The relationship between abundances of meiofauna and their suspected microbial food (diatoms and bacterial. Estuar. cstl. Shelf Sci. 17: 381-394

Palmer, M. A. (1984). Invertebrate drift: behavioral experiments with intertidal meiobenthos. Mar. Behav. Physiol 10: $235-253$

Pfannkuche, O., Thiel, H. (1987). Meiobenthic stocks and benthic activity on the NE-Svalbard Shelf and in the Nansen Basin. Polar Biol. 7. 253-266

Rudnick, D. T. (1989). Time lags between the deposition and meiobenthic assimilation of phytodetritus. Mar. Ecol. Prog Ser. 50: 231-240

Rudnick, D. T., Elmgren, R., Frithsen, J. B. (1985). Meiofaunal 
prominence and benthic seasonality in a coastal marine ecosystem. Oecologia (Berl.) 67: 157-168

Sharp, J. H. (1974). Improved analysis for particulate carbon and nitrogen from seawater. Limnol. Oceangr 19: 984-989

Sherman, K. M., Meeter, D. A., Reidenauer, J. A. (1984). A technique for subsampling an abundant taxon while completely sorting other taxa. Limnol. Oceanogr. 29: 433-439

Shirley, T C. (1989). Ecology of Priapulus caudatus (Priapulida) in an Alaskan subarctic ecosystem. Bull. mar. Sci. (in press)

Shirley, T. C., Fleeger, J. W., Decho, A. W., Sturdevant, M. V (1987). Association of meiofauna with primary production and recruitment in a subarctic ecosystem - 1986. In: APPRISE Annual Report. Summary of 1986 APPRISE Research Program. University of Alaska Juneau, Juneau, p. $405-448$

Shirley, T C., Fleeger, J. W., McGregor, S. W., McNutt, L. (1988). Association of meiofauna with primary production and recruitment in a subarctic ecosystem - 1987. In: APPRISE Annual Report. Summary of 1987 APPRISE Research Program. University of Alaska Fairbanks, Juneau, p. 255-287

This article was presented by Dr R. M. Warwick, Plymouth, United Kingdom
Strickland, J. D. H., Parsons, T R. (1972). A practical handbook of seawater analysis. Bull. Fish. Res. Bd Can. 176

Sturdevant, M. V. (1987). The role of meiofauna in the diets and feeding ecology of postmetamorphic flatfish. M. S. thesis, University of Alaska Juneau

Townsend, D. W., Cammen, L. M. (1988). Potential importance of the timing of spring plankton blooms to benthicpelagic coupling and recruitment of juvenile demersal fishes. Biol. Oceanogr. 5: 215-229

Valderhaug, V A., Gray, J. S. (1984). Stable macrofauna community structure despite fluctuating food supply in subtidal soft sediments of Oslofjord, Norway. Mar. Biol. 82: 307-322

Widbom, B., Elmgren, R. (1988). Response of benthic meiofauna to nutrient enrichment of experimental marine ecosystems. Mar. Ecol. Prog. Ser. 42: 257-268

Ziemann, D. A., Conquest, L. D., Bienfang, P. K., Kanda, J. (1988). Patterns of primary production and sedimentation during the 1987 spring bloom in Auke Bay, Alaska. In: Vol. I. APPRISE Annual Report, SFOS APP87-100. School of Fisheries and Ocean Sciences, University of Alaska, Fairbanks, p. 29-194

Manuscript first received: March 5, 1989

Revised version accepted: June 30, 1989 